\title{
PENGARUH PENAMBAHAN GLISEROL DAN KITOSAN KULIT UDANG TERHADAP BIODEGRADASI DAN KETAHANAN AIR PLASTIK BIODEGRADABLE
}

\author{
Susi SOLEKAH ${ }^{1}$, NiA SASRIA ${ }^{1 *}$, DAN HIZKIA AlPHA DEWANTO ${ }^{1}$ \\ ${ }^{1}$ Program Studi Teknik Material dan Metarulgi, Institut Teknologi Kalimantan, \\ Jalan Soekarno Hatta KM 15, Kec. Balikpapan Utara, Balikpapan, Kalimantan Timur 76127, Indonesia \\ *alamat email korespondensi: niasasria@lecturer.itk.ac.id
}

\begin{abstract}
Informasi Artikel Abstrak/Abstract
Riwayat Naskah :

Diterima pada 27

Agustus 2021

Diterima setelah

direvisi pada 25

Desember 2021

Diterbitkan pada 31

Desember 2021

Kata Kunci:

Biodegradasi;

Gliserol; Kitosan;

Pati; Plastik

biodegradable.

Pada plastik biodegradable, aktivitas mikroorganisme menyebabkan plastik jenis ini dapat terdegradasi sehingga tidak berbahaya bagi lingkungan. Pada penelitian ini plastik dibuat dari bahan dasar pati kulit singkong. Untuk meningkatkan karakteristik dari plastik berupa fleksibilitas dibutuhkan penambahan gliserol guna menghasilkan plastik yang fleksibel, dengan memvariasikan gliserol dengan komposisi $2 \mathrm{~mL}, 4 \mathrm{~mL}$ dan $6 \mathrm{~mL}$. Untuk meningkatkan sifat mekanik dari plastik dibutuhkan penambahan kitosan, dengan memvariasikan kitosan dengan komposisi $0,5 \mathrm{~g}, 1 \mathrm{~g}$ dan $1,5 \mathrm{~g}$. Tujuan dari penelitian ini yaitu untuk mengetahui pengaruh dari gliserol dan kitosan terhadap kemampuan biodegradasi dan ketahanan air dari plastik biodegradable serta kemampuan biodegradasi dari plastik biodegradable dalam waktu 7 hari. Pada penelitian ini menggunakan metode pengujian berupa uji FTIR untuk mengetahui gugus fungsi pada sampel, uji ketahanan air (uji swelling) untuk mengetahui ketahanan air pada sampel, uji biodegradasi mengetahui kemampuan degradasi dari sampel dan uji mikroskop optik untuk mengidentifikasi struktur mikro dari sampel. Pada penelitian ini untuk hasil biodegradasi yang paling tinggi yaitu pada sampel dengan variasi $0,5 \mathrm{~g}$ kitosan dan $2 \mathrm{~mL}$ gliserol sebesar $35.43 \%$ dan untuk hasil biodegradasi yang paling rendah yaitu pada sampel dengan variasi 2 g kitosan dan $6 \mathrm{~mL}$ gliserol yaitu sebesar $12.20 \%$ sedangkan untuk hasil uji ketahanan air (uji swelling) yang paling tinggi yaitu pada sampel dengan variasi kitosan $0,5 \mathrm{~g}$ kitosan dan $2 \mathrm{~mL}$ gliserol sebesar $50.59 \%$ dan hasil yang paling rendah yaitu pada sampel dengan variasi $1 \mathrm{~g}$ kitosan dan $2 \mathrm{~mL}$ gliserol yaitu sebesar $28.90 \%$.
\end{abstract}

Keywords:

Biodegrability;

Glycerol; Chitosan;

Starch;

Biodegradable

plastic.

\begin{abstract}
In biodegradable plastics, the activity of microorganisms causes this type of plastic to be degraded so that it is not harmful to the environment. In this study plastic is made from the basic material of cassava skin starch. To improve the characteristics of plastics in the form of flexibility requires the addition of glycerol to produce flexible plastics, by varying glycerol with a composition of $2 \mathrm{~mL}, 4 \mathrm{~mL}$ and $6 \mathrm{~mL}$. To improve the mechanical properties of plastic requires the addition of chitosan, by varying chitosan with a composition of $0.5 \mathrm{~g}, 1 \mathrm{~g}$ and $1.5 \mathrm{~g}$. The purpose of this study was to determine the effect of glycerol and chitosan on the biodegradation and water resistance capabilities of biodegradable plastics and the biodegradable biodegradation capabilities of biodegradable plastics within 7 days. In this study used testing methods in the form of FTIR tests to find out the functional groups on samples, water resistance tests (swelling tests) to find out the water resistance in samples, biodegradation tests to find out the degradation capabilities of samples and optical microscope tests to identify the microstructure of the sample. In this study for the highest biodegradation results, namely in samples with variations of $0.5 \mathrm{~g}$ of chitosan and $2 \mathrm{~mL}$ glycerol of $35.43 \%$ and for the lowest biodegradation results, namely in samples with variations of $2 \mathrm{~g}$ of chitosan and $6 \mathrm{~mL}$ of glycerol That is $12.20 \%$ while for the results of the water resistance test (swelling test) the highest is in samples with a variation of $0.5 \mathrm{~g}$ of chitosan and $2 \mathrm{~mL}$ glycerol of $50.59 \%$ and the lowest result is in samples with variations of $1 \mathrm{~g}$ offlatosan and $2 \mathrm{~mL}$ glycerol which is $28.90 \%$.
\end{abstract}

\section{PENDAHULUAN}

Plastik merupakan salah satu contoh dari polimer kimia yang bermanfaat dalam memenuhi kebutuhan sehari-hari yaitu bisa digunakan sebagai mainan anak, botol kemasan, wadah peralatan makan, bahan pakaian, serta furnitur [1]. Plastik banyak digunakan oleh masyarakat Indonesia karena memiliki sifat yang ringan dan harga yang terjangkau [2]. Ada plastik yang bisa terurai namun membutuhkan waktu puluhan tahun serta proses pembakaran tidak dapat mengurangi limbah plastik karena berbahaya untuk kesehatan dan lingkungan sekitar [3]. Plastik sebagai bahan dasar pengemas 
banyak digunakan dalam kehidupan masyarakat. Selain untuk membungkus makanan, plastik jenis ini juga memiliki fungsi yaitu untuk menjaga makanan agar tetap bersih dan mengurangi kontaminasi dari mikroorganisme serta melindungi produk akibat dari kerusakan [4]. Namun selain peranan plastik yang begitu penting dalam kehidupan masyarakat, plastik juga menyebabkan permasalahan yaitu limbah. Bagian utama dari plastik yaitu polimer sintesis akan terdegradasi cukup lama bahkan sampai ratusan tahun. kelemahan dari plastik yang berasal dari turunan senyawa dalam minyak bumi yaitu nonrenewable source yang berarti sewaktu-waktu akan habis dan terjadinya pencemaran limbah plastik [5].

Plastik jika dibakar, emisi karbonnya dapat mencemari lingkungan. Produksi dari limbah plastik di Indonesia menghasilkan sampah domestik peringkat kedua hingga mencapai 5,4 juta ton per tahun [6]. Sampah domestik Indonesia berada pada peringkat kedua yaitu mencapai 5,4 juta ton per tahun [7]. Dampak negatif dari lingkungan dapat disebabkan salah satunya karena penggunaan dari plastik, hal ini terjadi karena degradasi yang terjadi cukup sulit hingga penumpukan dari sampah plastik mencemari lingkungan $[8,6]$.

Kemasan plastik yang ramah lingkungan terus diupayakan oleh ilmuan dan peneliti untuk dikembangkan menjadi plastik biodegradable. Bahan dasar plastik biodegradable yaitu selulosa, pati serta lemak. Oleh sebab itu, maka dibutuhkan jenis plastik baru yang dapat didaur ulang secara biologi karena kandungan bahan organiknya [9] .

Dalam pembuatan plastik biodegradable bahan utama yang sering digunakan yaitu berupa pati serta Poly Lactic Acid (PLA) [10]. Menurut [11] pati yang digunakan sebagai bahan dasar plastik, aman bagi lingkungan jika dibandingkan plastik biodegradable yang lebih cepat terdekomposisi 10 hingga 20 kali daripada plastik tradisional yang butuh 50 tahun untuk terdekomposisi secara alamiah. Karena menggunakan bahan alami, maka pati dikenal sebagai bahan kemasan paling efektif karena murah dan dapat terdegradasi dengan cepat [12].

Penggunaan plastik biodegradable bisa digunakan layaknya plastik konvensional pada umumnya namun aktivitas mikroorganisme serta senyawa yang dihasilkan tidak berbahaya untuk lingkungan serta air [13]. Plastik biodegradable menggunakan prinsip gelatinisasi yaitu dengan bahan dasar pati (starch). Senyawa dari bahan pembentuknya seperti pati, selulosa, dan lignin menyebabkan plastik biodegradable ini dapat didaur ulang [14].

Dalam kehidupan sehari-hari sering ditemui limbah, yaitu limbah dari kulit singkong. Pati dapat diambil dari kulit singkong karena memiliki unsur karbohidrat di dalamnya. Pada kulit singkong mengandung karbohidrat sebesar 4,55\% [8]. Tidak hanya sebagai pakan ternak, pati dalam kulit singkong juga dapat digunakan sebagai bahan baku. Pati yang cukup tinggi terkandung dalam kulit singkong bisa menjadi bahan dasar dari plastik biodegradable. Air digunakan untuk melarutkan pati kemudian dipanaskan hingga kandungan air menguap dan hanya menyisakan lapisan film yang sifatnya stabil serta kaku.

Namun plastik biodegradable dari pati saja masih memiliki kelemahan. Beberapa diantaranya yaitu tidak tahan panas, rendahnya sifat mekanis yang dihasilkan serta tidak mampu menahan air dan mikroorganisme. Kerapatan sifat mekanik bahan mempengaruhi sifat mekaniknya, dimana sifat mekanik dapat ditingkatkan melalui kerapatan suatu bahan.

Sifat mekanis pada plastik biodegradable dapat ditingkatkan dengan menambahkan zat aditif berupa kitosan. Kitosan merupakan perantara dari zat-zat yang menghasilkan ikatan silang pada suatu polimer dan hal inilah yang menyebabkan penambahan kitosan akan meningkatkan kekuatan. Kitosan diperoleh dari deasetilasi kitin, yang dapat ditemukan dalam kulit udang. Kulit udang dihasilkan dari limbah industri udang, restoran, dan limbah dari rumah tangga. Masih kurangnya pemanfaatan dari kulit karena masih sering dijumpai dalam kehidupan sehari-hari serta dibiarkan berserakan begitu saja. Selain itu bahan lain yang digunakan dalam plastik biodegradable yaitu plasticizer.

Untuk meningkatkan elastisitas dari plastik biodegradable maka digunakan penambahan gliserol. Gliserol sendiri merupakan plasticizer yang mampu meningkatkan nilai elongasi dari plastik biodegradable. Plasticizer ditambahkan guna menurunkan kekuatan intermolekuler, fleksibilitas film meningkat serta sifat barrier film nya menurun [15].

Penelitian ini memiliki tujuan yaitu untuk mengetahui pengaruh dari gliserol dan kitosan terhadap kemampuan biodegradasi dan ketahanan air dari plastik biodegradable serta kemampuan biodegradasi dari plastik biodegradable. Dalam penelitian ini juga menggunakan variasi konsentrasi kitosan dan gliserol yang belum ada sebelumnya. Hal ini diketahui berdasarkan eksperimen yang telah dilakukan oleh penulis.

Dalam penelitian sebelumnya, menurut [16] dimana waktu simpan film plastik biodegradasi dari 
pati kulit singkong mempengaruhi sifat mekaniknya. Pada penelitian tersebut diperoleh hasil terbaik yaitu pati sebanyak $12 \mathrm{~g}$ dengan tambahan gliserol $4 \mathrm{~mL}$, sehingga didapatkan kekuatan tarik $0,2122 \mathrm{kgf} / \mathrm{mm}$ serta $3,5 \%$ pemanjangan saat putus. Kemudian menurut [17] bahwa kitosan dengan komposisi 2, 1.5 dan $1 \mathrm{~g}$ serta gliserol dengan komposisi $1 \%, 1.5 \%$ dan $2 \%$. Hasil dari penelitian tersebut yaitu pada struktur mikro kitosan dengan 1 gr: $1 \%$ gliserol memiliki nilai persentase degradasi paling besar namun terdapat sedikit gelembung udara (pinhole) dan lekukan dibandingkan dengan variasi kitosan dengan komposisi 2 gr: $2 \%$ gliserol. Sedangkan menurut [18] bahwa sifat mekanik pada bioplastik dipengaruhi oleh komposisi pati kulit singkongkitosan dan gliserol (plasticizer). Pada kitosan 2\%, gliserol $3 \mathrm{~mL}$ merupakan komposisi terbaik bioplastik. Dalam penelitian lain, penambahan gliserol sebanyak $2 \mathrm{~mL}$ dan $1 \mathrm{~g}$ kitosan merupakan komposisi optimum dengan hasil optimum kuat tarik sebesar 0,00245 MPa dan \% ketahanan air sebesar 64,79\% [17]. Hal ini yang menjadi dasar pemilihan dari penggunan konsentrasi kitosan dan gliserol dalam penelitian ini.

\section{EKSPERIMEN}

\section{Material}

Dalam penelitian ini memerlukan bahan yang meliputi pati kulit singkong yang didapatkan dari penjual singkong di Pasar Pandansari, Kecamatan Balikpapan Barat, Kota Balikpapan, Kalimantan Timur, kitosan kulit udang 100 mesh dibeli dari e-commerce, asam asetat glasial 3\% merek Pudak yang telah diencerkan, alkohol 96\% antiseptik merek Calmo, amidis dan gliserol $\left(\mathrm{C}_{3} \mathrm{H}_{8} \mathrm{O}_{3}\right)$ merek Merck.

\section{Instrumentasi}

Alat yang digunakan dalam proses pembuatan pati kulit singkong yaitu baskom, oven, blender. Kemudian untuk preparasi kitosan kulit udang menggunakan ayakan mesh 100 sedangkan untuk pembuatan plastik biodegradable menggunakan beaker glass merek Duran, pengaduk kaca, magnetik stirer merek Thermo dan magnetik bar, corong kaca Herma, labu ukur Pyrex, pipet volume merek Iwaki dan pipet tetes, spatula, tabung ukur merek Pyrex, timbangan analitik merek Boeco, oven listrik merek Primax, cetakan kue diameter $16 \mathrm{~cm}$, alat uji FTIR merek Alpha II dan mikroskop optik merek Euromex DelphiX Observer.

\section{Prosedur}

\section{Pembuatan Pati Kulit Singkong}

Pati kulit singkong dibuat dengan tahapan yaitu kulit singkong dipisahkan dari kulit arinya. Kemudian air mengalir digunakan untuk mencuci kulit singkong. Setelah itu, kulit singkong dihaluskan menggunakan blender. Kemudian dilakukan penyaringan dan didapatkkan endapan hasil penyaringan. Pati akan mengendap menjadi pasta. Kemudian pasta yang didapatkan dikeringkan dengan menggunakan oven. Setelah kering, produk dihaluskan dan dilakukan pengayakan sehingga didapatkan serbuk berukuran 100 mesh.

\section{Pembuatan Plastik Biodegradable}

Dalam penelitian ini menggunakan kitosan kulit udang dengan variasi $0,5 \mathrm{~g}, 1 \mathrm{~g}$ dan $1,5 \mathrm{~g}$ serta gliserol dengan variasi $2 \mathrm{~mL}, 4 \mathrm{~mL}$ dan $6 \mathrm{~mL}$. Pada pembuatan plastik biodegradable mula-mula serbuk pati kulit singkong dilarutkan dalam $20 \mathrm{~mL}$ asam asetat yang telah diencerkan dan diaduk menggunakan magnetik stirrer selama 15 menit. Selanjutnya, serbuk kitosan kulit udang dilarutkan dalam $50 \mathrm{~mL}$ asam asetat yang telah diencerkan dan d magnetik stirrer digunakan untuk mengaduk selama 30 menit. Larutan kitosan kulit udang dan larutan pati kulit singkong kemudian dicampurkan menggunakan magnetik stirrer selama 30 menit hingga homogen, diikuti dengan penambahan gliserol. Setelah itu, dilakukan pengovenan selama 24 jam dan pencetakan menggunakan cetakan kue.

\section{Pengujian FTIR}

Dalam pengujian FTIR menggunakan sampel dari pati kulit singkong sebanyak $1 \mathrm{~g}$. Kemudian didapatkan hasil spektra pada sampel pati kulit singkong yang kemudian dianalisa gugus fungsinya.

\section{Uji Ketahanan Air (Uji Swelling)}

Dalam uji ketahanan air (uji swelling) menggunakan 9 variasi plastik biodegradable yang dipotong dengan ukuran $2 \times 2 \mathrm{~cm}$, sehingga didapatkan 9 sampel untuk kemudian dilakukan pengujian ketahanan air.

\section{Uji Biodegradasi}

Dalam pengujian biodegradasi menggunakan 9 variasi sampel plastik biodegradable yang tiap variasinya dibutuhkan 4 sampel dan kemudian dipotong dengan ukuran $2 \times 2$ 
$\mathrm{cm}$. Sehingga didapatkan 36 sampel untuk kemudian dilakukan uji biodegradasi. Uji biodegradasi dilakukan dalam waktu 7 hari dengan pengecekkan pada hari ke-1, ke-3, ke-5 dan ke-7.

\section{HASIL DAN PEMBAHASAN}

\section{Hasil Analisis Spektroskopi Fourier Transform Infrared (FTIR)}

Sampel pati digunakan untuk menganalisis FTIR guna mengidentifikasi gugus fungsi pada sampel. Pada pengujian FTIR pati kulit singkong dapat didapatkan hasil pada Gambar 1.

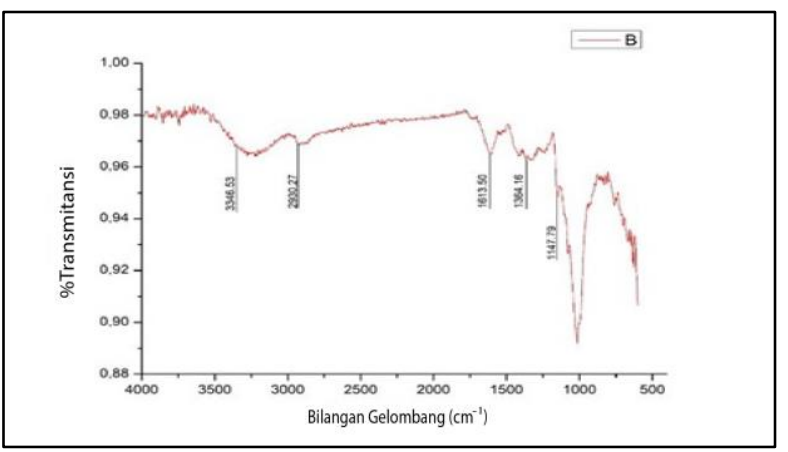

Gambar 1. Spektra pati kulit singkong.

Berdasarkan Gambar 1 terdapat beberapa gugus fungsi pada pati kulit singkong. Gugus fungsi tersebut disajikan pada Tabel 1.

Tabel 1. Gugus Fungsi Pada Spektrum Pati Kulit Singkong.

\begin{tabular}{ccc}
\hline No & $\begin{array}{c}\text { Ikatan Gugus } \\
\text { Fungsi }\end{array}$ & $\begin{array}{c}\text { Bilangan Gelombang } \\
\left(\mathrm{cm}^{-1}\right)\end{array}$ \\
\hline 1 & O-H & 3346,53 \\
2 & C-H & 2930,27 \\
3 & C=O & 1613,50 \\
4 & C-O & 1364,16 \\
5 & C-N & 1147,79 \\
\hline
\end{tabular}

Berdasarkan Tabel 1 terlihat bahwa pada pati kulit singkong mengandung gugus fungsi aktif antara lain gugus $\mathrm{O}-\mathrm{H}$ merupakan gugus fungsi hidroksil yang ditunjukkan dengan serapan lebar pada daerah $3346,53 \mathrm{~cm}^{-1}$. Kemudian terdapat gugus fungsi $\mathrm{C}-\mathrm{H}$ merupakan gugus fungsi alkana pada bilangan gelombang 2930,27 $\mathrm{cm}^{-1}$, selanjutnya untuk bilangan gelombang pada serapan $1613,50 \mathrm{~cm}^{-1}$ yaitu teridentifikasi adanya gugus fungsi $\mathrm{C}=\mathrm{O}$ yaitu karbonil, gugus fungsi $\mathrm{C}$ $\mathrm{O}$ pada bilangan gelombang $1364,16 \mathrm{~cm}^{-1}$ mengindikasi adanya gugus fungsi ester, serta serapan pada bilangan gelombang $1147,79 \mathrm{~cm}^{-1}$ mengidentifikasi adanya gugus fungsi $\mathrm{C}-\mathrm{N}$ yaitu nitril.
Menurut [19] dalam pati kulit singkong mengandung amilosa sebanyak 18 \%ratio dan amilopektin sebanyak 82 \%ratio. Hal ini berdasarkan uji FTIR yaitu terdapat gugus fungsi aktif berupa hidroksil yang mengindikasi adanya amilopektin dan amilosa di dalam pati kulit singkong. Pada pati yang dapat larut dan terdegradasi di alam mengandung gugus fungsi hidroksil karena merupakan gugus fungsi utama penyusun amilosa dan amilopektin [19].

\section{Hasil Uji Ketahanan Air (Uji Swelling)}

Dengan menggunakan rumus dibawah ini maka dapat diketahu hasil dari uji ketahanan air (uji swelling)

$\operatorname{Air}(\%)=\frac{\mathrm{W}-\mathrm{W} 0}{\mathrm{~W} 0} \times 100 \%$

Kemudian didapatkan gafik seperti pada Gambar 2.

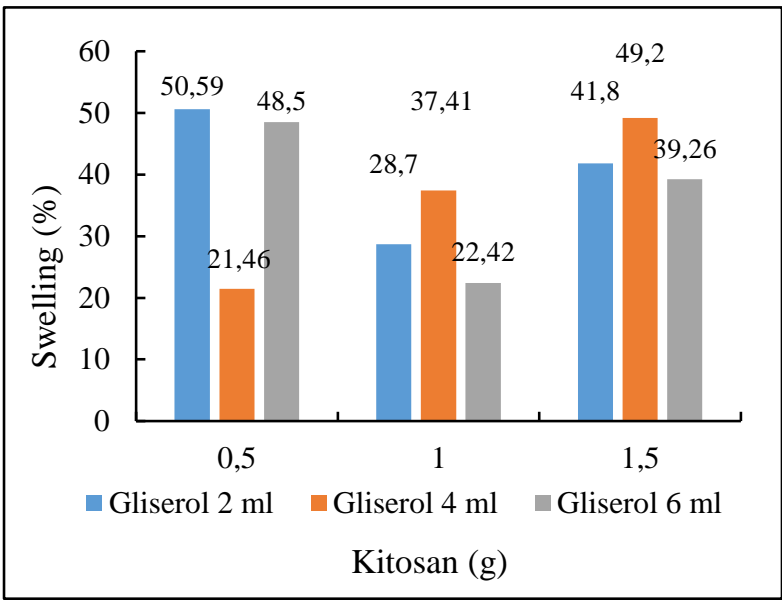

Gambar 2. Hasil Uji Ketahanan Air (Uji Swelling).

Dari Gambar 2 didapatkan hasil untuk uji ketahanan air (uji swelling) terendah yaitu pada sampel D (0,5 g kitosan: $4 \mathrm{~mL}$ gliserol) serta hasil untuk uji ketahanan air (uji swelling) tertinggi yaitu pada sampel A (0,5 g kitosan: $2 \mathrm{~mL}$ gliserol). Menurut presentase ketahanan air meningkat seiring dengan peningkatan dari kitosan pada plastik biodegradable. Namun dalam penelitian ini didapatkan hasil data yang tidak konstan untuk penambahan kitosan terhadap nilai uji ketahanan air (uji swelling). Sedangkan menurut teori, penambahan gliserol menyebabkan nilai uji ketahanan air (uji swelling) menurun. Namun dalam penelitian ini, juga didapatkan hasil data yang tidak konstan untuk penambahan gliserol terhadap nilai uji ketahanan air (uji swelling). Hal ini menunjukkan bahwa plastik biodegradable dari kitosan kulit udang dan pati kulit singkong serta penambahan gliserol tidak memiliki ketahanan air 
yang baik sehingga perlu dilakukan penelitian lanjutan dengan menambahkan zat aditif lain guna meningkatkan ketahanan air.

Menurut [20] bahwa film plastik terhadap air dipengaruhi oleh fraksi kitosan, yaitu ketahanan film plastik terhadap air akan semakin baik jika semakin besar fraksi kitosan yaitu dengan water uptake memiliki nilai terbaik.

Tabel 2. Penimbangan pada sampel.

\begin{tabular}{ccc}
\hline No. & Sampel & Penimbangan (kali) \\
\hline 1 & A & 9 \\
2 & B & 9 \\
3 & C & 3 \\
4 & D & 4 \\
5 & E & 1 \\
6 & F & 3 \\
7 & G & 8 \\
8 & H & 4 \\
9 & I & 8 \\
\hline
\end{tabular}

Pada Tabel 2 didapatkan hasil data yang tidak konstan. Hal ini disebabkan pada saat uji ketahanan air (uji swelling), perendaman dilakukan selama 10 detik secara berulang-ulang sampai sampel tidak mampu menyerap air. Dalam penelitian ini hanya menggunakan 1 sampel tiap variasi penelitian sehingga memungkinkan terjadinya anomally (penyimpangan).

\section{Hasil Uji Biodegradasi}

Hasil uji biodegradasi dengan menggunakan media tanah dilakukan selama 1 minggu. Hal ini menginformasikan mengenai kemampuan degradasi dari sampel plastik biodegradable yang dikubur dalam tanah. Grafik presentase degradasi pada hasil uji biodegradasi dapat dilihat pada Gambar 3.

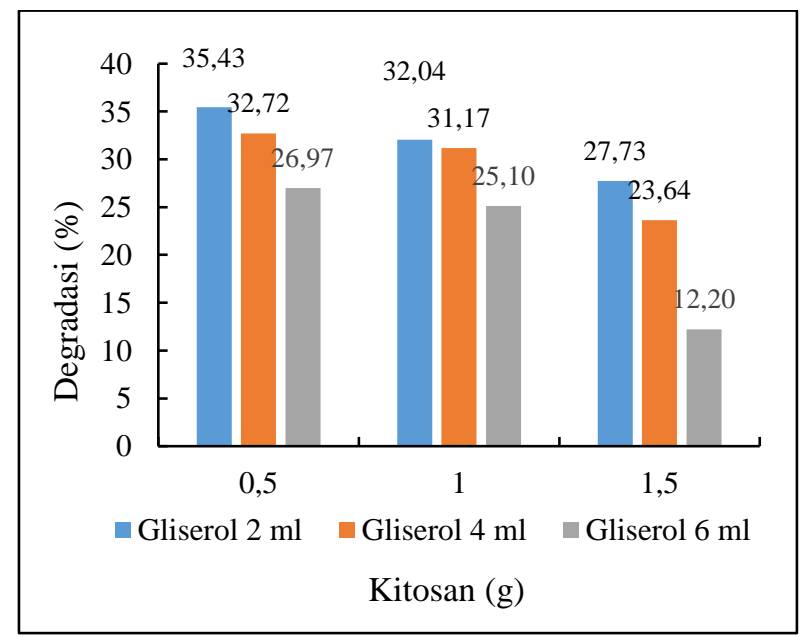

Gambar 3. Pengaruh Presentase Kitosan Kulit Udang dan Gliserol Terhadap Persen Degradasi
Uji biodegradable pada penelitian ini dilakukan dengan menggunakan metode soil burial test. Metode ini memanfaatkan media tanah guna pengamatan dari pengurangan massa (biodegradable) pada sampel, parameter yang diukur yaitu berupa pengurangan massa dari sampel yang telah ditimbun dalam medium tanah selama waktu tertentu. Penanaman sampel plastik biodegradable pada media tanah dengan $\mathrm{pH}$ netral selama 1 minggu. Tahapan dari uji biodegradasi yang dilakukan yaitu menimbang massa sampel sebelum dan sesudah proses biodegradasi dalam rentang waktu tertentu. Jika semakin besar terjadi penurunan massa maka menunjukkan bahwa sampel tersebut akan semakin cepat terdegradasi.

Berdasarkan Gambar 3, rata-rata sampel plastik biodegradable mengalami penurunan. Nilai persentase degradasi yang paling tinggi yaitu pada sampel A dengan persentase degradasi sebesar $35.43 \%$ serta nilai presentase degradasi paling rendah yaitu pada sampel I dengan persentase degradasi sebesar $12.20 \%$. Hal ini menunjukkan bahwa semakin rendah komposisi kitosan dan gliserol maka akan semakin cepat sampel plastik biodegradable terurai di alam. Pada Gambar 3 juga terlihat bahwa penambahan kitosan terhadap nilai persentase degradasi yaitu berbanding terbalik. Semakin besar penambahan kitosan maka nilai persen degradasinya akan semakin menurun.

\section{Hasil Uji Mikroskop Optik}

Setelah melakukan uji biodegradasi dan mendapatkan sampel dengan nilai degradasi tertinggi dan terendah. Selanjutnya, dilakukan pengujian mikroskop optik pada kedua sampel plastik biodegradable.

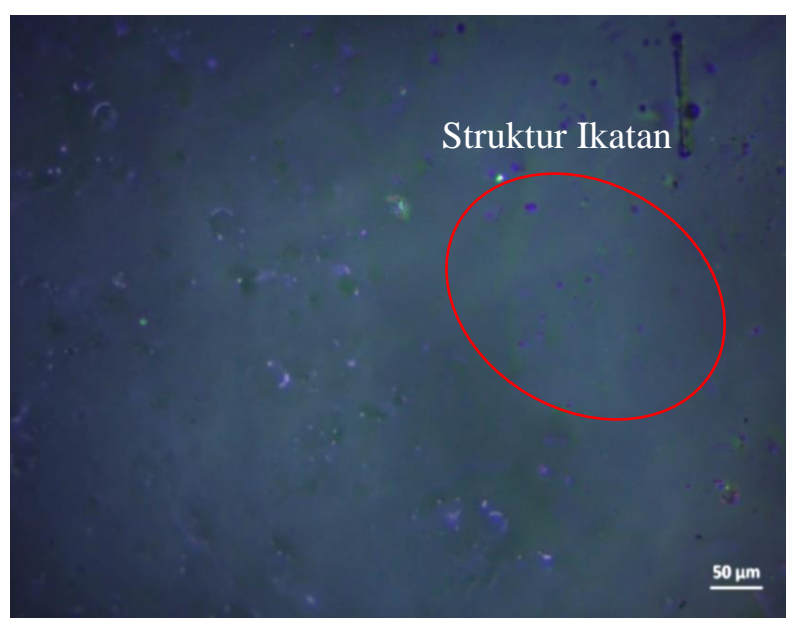

Gambar 4. Hasil mikroskop optik sampel A $(0,5 \mathrm{~g}$ kitosan: $2 \mathrm{~mL}$ gliserol) perbesaran 50x.

Pada Gambar 4 merupakan sampel dengan nilai degradasi yang tertinggi. Pada gambar 
tersebut terlihat bahwa struktur ikatan pada plastik biodegradable tidak rapat. Oleh sebab itu, mikroorganisme mudah untuk memutus struktur ikatan dan menyebabkan plastik biodegradable menjadi lebih cepat terdegradasi di tanah.

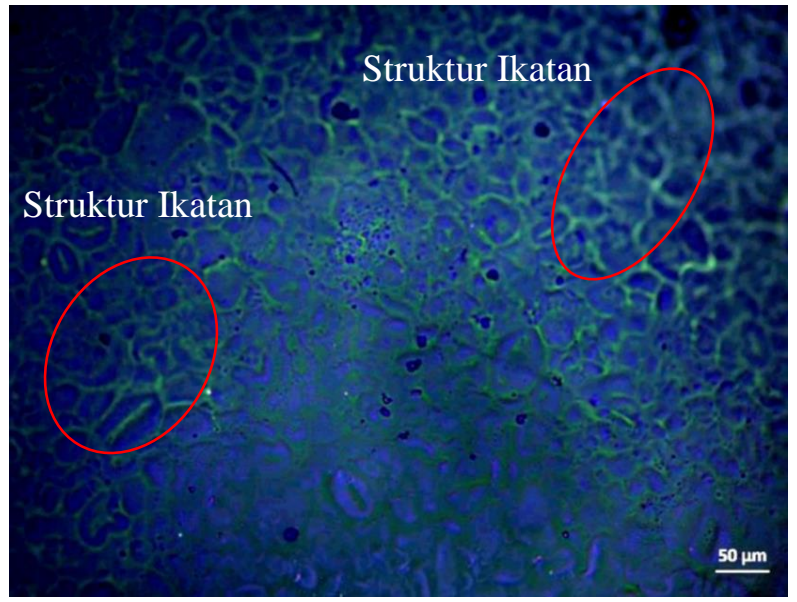

Gambar 5. Hasil Mikroskop Optik Sampel I (1,5 g Kitosan: 6 mL Gliserol) Perbesaran 50x.

Sampel dengan nilai degradasi terendah ditunjukkan pada Gambar 5. Pada gambar tersebut diketahui bahwa partikelnya berikatan antara satu dengan yang lainnya dan tergolong cukup rapat. Penambahan kitosan menyebabkan struktur ikatan pada plastik biodegradable menjadi lebih rapat sehingga mikroorganisme membutuhkan waktu yang lama dalam memutus ikatan tersebut. Hal ini menyebabkan plastik biodegradable tersebut menjadi lebih lama terdegradasi di tanah.

\section{SIMPULAN}

Berdasarkan hasil penelitian dapat disimpulkan pada uji FTIR terkonfirmasi bahwa pada pati kulit singkong benar mengandung gugus fungsi aktif berupa hidroksil yang menunjukkan adanya amilosa dan amilopektin. Berdasarkan hasil pengujian biodegradasi, diketahui bahwa dengan bertambahnya konsentrasi gliserol maka nilai persentase degradasi plastik biodegradable akan semakin kecil dan nilai persentase degradasi plastik biodegradable akan semakin kecil seiring dengan semakin beratnya kandungan dari kitosan. Namun untuk uji ketahanan airnya, plastik biodegradable ini tidak memiliki ketahanan air yang baik sehingga perlu dilakukan penelitian lanjutan dengan menambahkan zat aditif lain guna meningkatkan ketahanan air. Hal ini dikarenakan pada penelitian ini hanya menggunakan 1 sampel tiap variasi penelitian sehingga memungkinkan terjadinya anomally (penyimpangan).

\section{UCAPAN TERIMA KASIH}

Terimakasih kepada Institut Teknologi Kalimantan (ITK) dan Laboratorium Terpadu ITK yang telah memfasilitasi pelaksanaan kegiatan penelitian ini.

\section{REFERENSI}

[1] S.I. Bayer, S. Guzman-Puyol, J. HerediaGuerrero, L. Cosseracciu, R. Ruffilli, and R. Cingolani, "Direct transformation of edible vegetable waste into bioplastic", Journal of Macromolecules, vol. 47, no. 15, pp. 51355143, 2014.

[2] Syaubari, S. Safwani, and M. Riza, "Synthesis of biodegradable plastic from tapioca with n-isopropylacrylamid and chitosan using glycerol as plasticizer", Journal of Science and Engineering, vol. 345, 2018.

[3] M.S. Muhsin, Sudrajat, and R. Kusuma, "Pemanfaatan limbah kulit buah lai durio kutejensis (Hassk) Becc. sebagai antibakteri dari bakteri", Samarinda: Prosiding Seminar Sains dan Teknologi FMIPA Unmul, pp. 399-403, 2016.

[4] N.P. Mahalik and A.N. Nambiar, "Trends in food packaging and manufacturing systems and technology", Journal of Trends In Food Science \& Technology, vol. 21, pp. 117-128, 2012.

[5] Dani, I. Made, and L. Johar, "Pembuatan dan karakterisasi polimer ramah lingkungan berbahan dasar glukomanan umbi porang", Jurnal Sains dan Seni Pomits, vol. 1, no. 1, pp. 1-6, 2012.

[6] Y. Tokiwa, "Biodegrability of plastics", International Journal of Molecular Sciences, vol. 10, no. 10, pp. 3722, 2012.

[7] F. Gironi aand V. Piemonte, "Bioplastics and petroleum-based plastics", Energy Source, pp. 1949-1959, 2011.

[8] Hidayat, "Peluang penggunaan kulit singkong sebagai pakan unggas", Jurnal Pengembangan Penyuluhan Pertanian, vol. 14, no. 25, 2009.

[9] G.P. Lazuardi and S.E. Cahyaningrum, "Pembuatan dan karakterisasi bioplastik berbahan dasar kitosan dan pati singkong dengan plasticizer gliserol", Journal of Chemistry, vol. 2, no. 3, pp. 161-166, 2013.

[10] P. Coniwanti, "Pembuatan film plastic biodegradable dari pati jagung dengan penambahan kitosan dan pemlastis gliserol", 
Jurnal Teknik Kimia, vol. 20, no. 4, pp. 2230, 2014.

[11] T. Huda and F. Firdaus, "Karakteristik fisikokimiawi film plastik biodegradable dari komposit pati singkong-ubi jalar", LOGIKA, vol. 4, pp. 5-7, 2007.

[12] H.M. Park, S.R. Lee, S.R. Chowdhury, and T.K. Kang, "Tensile properties, morphology, and biodegradability of blend of starch with various thermoplastics", Journal of Applied Polymer Science, vol. 86, pp. 2907-2915, 2002.

[13] P. Sinaga, "Pasar moders vs pasar tradisional", Jurnal Pengkajian Koperasi dan UKM, pp. 85-99, 2014.

[14] L. Averous, "Biodegradable multiphase systems based on plasticized starch", Journal of Macromolecular Science, vol. 44, no. 3, pp. 231-274, 2014.

[15] Tokura and Nishi, "Specification and characterization of kitin and kitosan", Universitas Kebangsaan Malaysia, pp. 6778, 2014.

[16] F. Akbar, Z. Anita, and H. Harahap, "Pengaruh waktu simpan film plastik biodegradasi dari pati kulit singkong terhadap sifat mekanikalnya", Jurnal Teknik Kimia USU, vol. 2, no. 2, pp. 11-15, 2013.
[17] N. Sasria, Asrilsyah, M.P.D. Lubis, A. Zulfikar, and R.A. Tanjung, "Sintesis dan karakterisasi plastik biodegradable berbasis pati nasi aking dan kitosan cangkang udang", Jurnal Sains dan Teknologi, vol. 16, no. 2, pp. 231-236, 2020.

[18] I.G. Sanjaya and T. Puspita, "Pengaruh penambahan khitosan dan plasticizer gliserol pada karakteristik plastik biodegradable dari pati limbah kulit singkong", Laboratorium Pengolahan Limbah Industri Jurusan Teknik Kimia, 2013.

[19] Hilwatullisan, "Pengaruh kitosan dan plasticizer gliserol dalam pembuatan plastik biodegradable dari pati talas", Prosiding Seminar Nasional Badan Standarisasi dan Kebijakan Jasa Industri, vol. 2, no. 2, 2019.

[20] A.F. Nugroho, "Sintesis bioplastik dari pati ubi jalar menggunakan penguat logam zno dan penguat alami clay", Jurnal Litbang Industri Baristand Industri Padang, vol. 5, no. 2, 2012.

[21] Oktavia, "Studi awal pemisahan amilosa dan amilopektin pati ubi jalar (Ipomoea Batatas Lam) pangan variasi konsentrasi", Jurnal Kimia dan Kemasan, vol. 2, no. 3, pp. 153156, 2013. 